\section{Gold-Catalyzed Synthesis of Oxetan-3-ones from Propargylic Alcohols}

Synthesis of Heterocycles

Key words

oxetan-3-ones

propargylic alcohols

gold<smiles>C#CC(O)O</smiles>

(2-biphenyl)Cy $\mathrm{Cy}_{2} \mathrm{AuNTf}_{2}$ (5 mol\%) 10 (2 equiv), $\mathrm{Tf}_{2} \mathrm{NH}$ (1.2 equiv) DCE, r.t., 3-4 h

1<smiles>CCC1OCC1=O</smiles>

3

9 examples
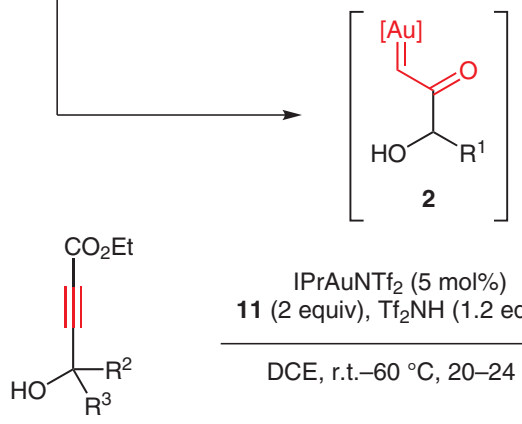

IPrAuNTf 2 (5 mol\%) 11 (2 equiv), $\mathrm{Tf}_{2} \mathrm{NH}$ (1.2 equiv)

DCE, r.t. $-60^{\circ} \mathrm{C}, 20-24 \mathrm{~h}$

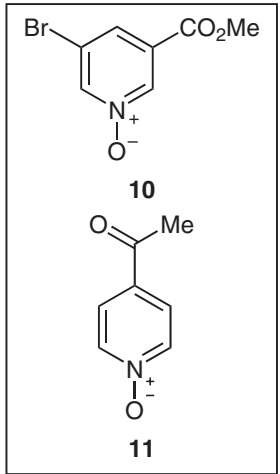

$\mathrm{R}^{1}=\mathrm{Cy}, n$-Hept, $\left(\mathrm{CH}_{2}\right)_{2} \mathrm{Ph}$, $\left(\mathrm{CH}_{2}\right)_{3} \mathrm{CH}=\mathrm{CH}_{2},\left(\mathrm{CH}_{2}\right)_{3} \mathrm{OMOM}$,

$\left(\mathrm{CH}_{2}\right)_{4} \mathrm{NHBoc},\left(\mathrm{CH}_{2}\right)_{4} \mathrm{~N}_{3},\left(\mathrm{CH}_{2}\right)_{4} \mathrm{Br}, \mathrm{Ph}$ $\mathrm{R}^{2}=\mathrm{H}, \mathrm{Me}$

$\mathrm{R}^{3}=\mathrm{Me}, n-\mathrm{Pr}, i-\mathrm{Pr}$, ОВOM

$\mathrm{R}^{2}-\mathrm{R}^{3}=-\left(\mathrm{CH}_{2}\right)_{4^{-},},-\left(\mathrm{CH}_{2}\right)_{5^{-},},-\left(\mathrm{CH}_{2}\right)_{6^{-}}$, adamantyl

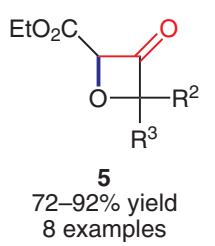

Significance: The gold-catalyzed synthesis of oxetan-3-ones $\mathbf{3}$ from propargylic alcohols $\mathbf{1}$ is reported. A range of substituents $\left(R^{1}\right)$ are tolerated, including acid labile (OMOM, NHBoc) and reactive $\left(\mathrm{N}_{3}, \mathrm{Br}\right)$ groups. Tertiary propargylic alcohols $\mathbf{4}$ are also suitable substrates, although the electronwithdrawing ester is required to prevent the formation of undesired propargylic cations under the acidic reaction conditions. This methodology may also be used to prepare the volatile and expensive oxetan-3-one 7, which may be converted, without purification, into useful oxetane derivatives $\mathbf{8}$ and 9.
Comment: Oxetan-3-ones serve as highly useful synthetic intermediates, as a surrogate for the gem-dimethyl group, and as mimics in drug discovery. Despite this utility, they typically require multi-step, low-yielding syntheses. The current process delivers oxetan-3-ones in one step from simple and readily available starting materials under mild conditions. The intermediate $\alpha$-oxo gold carbene is generated from a simple alkyne, bypassing the traditional method for carbenoid generation using hazardous $\alpha$-diazo ketones. Importantly, the commercially available (but expensive) parent oxetan-3-one may be prepared in high yield from inexpensive propargyl alcohol.

SYNFACTS Contributors: Victor Snieckus, Timothy Hurst DoI: 10.1055/s-0030-1258618; Reg-No.: V11710SF 